\title{
INVESTIGATION AND OPTIMIZATION SYNTHESIS PATHWAY OF ANTIBACTERIAL DRUG ETHONIUM
}

\author{
G.V. Tsaplin' ${ }^{1}$, S.S. Grishin ${ }^{1}$, E.P. Baberkina ${ }^{1}$, S.V. Popkov ${ }^{1}$, V.S. \\ Talismanov $^{2, \varpi}$, O.G. Karmanova ${ }^{2}$ and S.S. Zykova ${ }^{3}$ \\ ${ }^{1}$ Department of Chemistry and Technology of Organic Synthesis, D. Mendeleev University of \\ Chemical Technology of Russia, Moscow, Russian Federation \\ ${ }^{2}$ Depatment of Chemistry, Moscow Institute of Physics and Technology, Dolgoprudny, Moscow \\ Region, Russian Federation \\ ${ }^{3}$ Department of Pharmacology, Perm State Pharmaceutical Academy, Perm, Russian Federation \\ ${ }^{\square}$ Corresponding Author: talismanovpharm@mail.ru
}

\begin{abstract}
This work is devoted to optimization the synthetic pathway of the antibacterial drug Ethonium. The drug was synthesized by a three-stage scheme. We have proposed a technologically available and cheap scheme synthesis of Ethonium. The stages for preparation of decyl 2-chloroacetate and TMEDA were investigated and optimal conditions for their synthesis were determined. The total yield of Ethonium achieved $20 \%$ and it's higher than described earlier. Keywords: Decyl-2-chloroacetate, Eschweiler-Clarke Methylation of Amines, Ethonium, Gemini Cationic Surfactants, Fungicidal Activity, N1, N1,N2,N2-tetramethylethane-1,2-diamine.

RASĀYAN J. Chem., Vol. 14, No.3, 2021
\end{abstract}

\section{INTRODUCTION}

Gemini surfactants, such as quaternary ammonium salts, are commonly used in many medicinal, agricultural, industrial applications because of their biological and chemical properties and also because of their synthetic availability. The first reason is the great solubility and foam properties. The second reason is low critical micelle concentration (CMC). Gemini surfactants belong to an ionic type of surfactants and are used as a supporting agent in different types of treatment microbial diseases. Nowadays action mechanism of quaternary gemini surfactants is already researched ${ }^{1}$, and consists of absorption on the membrane of bacterial cell and membrane or cell wall destruction of bacteria ${ }^{2}$, some authors note different breaches in the structure of bacteria's DNA. ${ }^{3,4}$ The most popular biologically active gemini surfactants are cationic gemini surfactants (near 90\%). ${ }^{5}$ It is related to the negative charge of the bacteria membrane. ${ }^{6}$ The positive charge of surfactant helps to absorb at the surface of bacteria and increases the antibacterial activity of the agent. Dimeric gemini surfactants contribute to increasing the absorption of drugs with low solubility. ${ }^{7-10}$ Gemini surfactants as antibacterial drugs are represented on the market, for example, Dequalinium chloride ${ }^{1}$ and Ethonium. ${ }^{11}$ Ethonium is an antiseptic, disinfectant drug with antibacterial, fungicidal activity. It has some positive effects such as analgesic effect, inhibition of inflammatory process and its low toxicity. Fungicidal activity of Ethonium and homologs was investigated by Oblack and coworkers. ${ }^{12}$ They showed that most active molecules had ethylendiamine spacer group and decyl radical in ether group, such as Ethonium molecule. There are studies on the use of Ethonium as an angioprotector in treating experimental atherosclerosis. ${ }^{13}$ Babak and coworkers proved the efficiency using of Ethonium in the treatment of patients with gastric and duodenal peptic ulcers. ${ }^{14,15}$ Nowadays problems of Ethonium manufacturing are low yields at key studies of synthesis. The current study is focused on optimization of key studies such as synthesis of alkylation agent, obtaining of $\mathrm{N}^{1}, \mathrm{~N}^{1}, \mathrm{~N}^{2}, \mathrm{~N}^{2}$ - tetramethylethane-1,2-diamine and alkylation of tertiary amine. Some alternative methods of decyl-2-chloroacetate were studied and determined influence of temperature and solvent at Eschweiler-Clarke methylation of ethylenediamine study. It should help to find an optimal conditions for the synthesis of Ethonia. 


\section{Material and Methods}

\section{EXPERIMENTAL}

The chemicals, solvents, reagents were used of high-graded quality and without purification obtained from Sigma Aldrich. Melting points of the compounds were defined in open capillaries and were uncorrected. ${ }^{1} \mathrm{H}$ NMR spectra were recorded on Bruker AM-300 instrument (300.13 MHz). MS spectrum of ethonium was recorded on Surveoyr MSQ Thermo Finnigan in ESI mode. The reaction course and the purity of the obtained compounds were monitored by TLC (Sorbfil A-UV or Silufol UV-254). The data of the element analysis were close or coincided with the calculated data.

\section{Synthesis of decyl-2-chloroacetate}

In a $100 \mathrm{~cm}^{3}$ round-bottom flask, equipped with a condenser with a calcium chloride tube and a magnetic stirrer, 0.072 moles (1.2 eq.) 2-chloroacetic acid, $5.45 \cdot 10^{-5}$ mole (0.001 eq.) 4-methylbenzenesulfonic acid monohydrate $(\mathrm{TsOH})$ in $40 \mathrm{ml}$ mixture of xylenes were placed. Then 0.06 mole $(1 \mathrm{eq}$.) decanol was added dropwise to the reaction mixture. The reaction mixture was refluxed with a condenser for $1.5 \mathrm{~h}$ and $3.5 \mathrm{~h}$ with the Dean-Stark trap. Finally, the mixture was cooled to RT, shaken with $50 \mathrm{ml}$ of saturated $\mathrm{NaHCO}_{3}$ solution. After separation, the organic layer was dried under anhydrous $\mathrm{MgSO}_{4}$ for $24 \mathrm{~h}$. Then the mixture was filtered off and the solvent was evaporated. Yield 83\%. b.p. $185-190{ }^{\circ} \mathrm{C}$ (58.8 Torr), $\mathrm{n}^{20}{ }_{\mathrm{d}}=1.4426$. $\mathrm{NMR}^{1} \mathrm{H}\left(\mathrm{d}_{6}-\mathrm{DMSO}, \delta, \mathrm{ppm}, J / \mathrm{Hz}\right): 0.87\left(\mathrm{t}, 3 \mathrm{H}, \mathrm{CH}_{3} \mathrm{CH}_{2} \mathrm{CH}_{2},{ }^{3} \mathrm{~J}=7.2\right) ; 1.20-1.35\left(\mathrm{~m}, 14 \mathrm{H},\left(\mathrm{CH}_{2}\right)_{7}\right) ; 1.61$ (q, $\left.2 \mathrm{H}, \mathrm{OCH}_{2} \mathrm{CH}_{2}, \mathrm{~J}^{3}=7.2, \mathrm{~J}^{3}=6.8\right) ; 4.12\left(\mathrm{t}, 2 \mathrm{H}, \mathrm{OCH}_{2}, \mathrm{~J}^{3}=6.8\right) ; 4.33\left(\mathrm{~s}, 2 \mathrm{H}, \mathrm{CH}_{2} \mathrm{Cl}\right)$.

\section{Synthesis of $\mathbf{N}^{1}, \mathbf{N}^{1}, \mathbf{N}^{2}, \mathbf{N}^{2}$ - tetramethylethane-1,2-diamine}

In a $100 \mathrm{~cm}^{3}$ round-bottom flask, equipped with a condenser, a magnetic stirrer, a dropper and addition funnel 0.42 mole (8.4 eq.) formic acid ( $85 \%)$ and 0.25 mole (5 eq.) formaldehyde solution (40\%) was placed. The reaction mixture was stirred and gently heated to $78-80{ }^{\circ} \mathrm{C}$. Then 0,05 mole ( 1 eq.) ethylenediamine was added within 1 hour. The mixture was refluxed for $9 \mathrm{~h}$, water, formic acid and formaldehyde were evaporated. Then $20 \mathrm{ml}$ aqueous sodium hydroxide (40\%) solution was added, the organic layer was separated and dried $(\mathrm{NaOH})$. The crude reaction product was distilled at atmospheric pressure. Yield 98\%, b.p. $119-122{ }^{\circ} \mathrm{C}, \mathrm{n}^{20}{ }_{\mathrm{d}}=1.4225$. $\mathrm{NMR}^{1} \mathrm{H}\left(\mathrm{d}_{6}-\mathrm{DMSO}, \delta\right.$.ppm, $\left.\mathrm{J} / \mathrm{Hz}\right): 2.24\left(\mathrm{~s}, 12 \mathrm{H}, \mathrm{CH}_{3} \mathrm{~N}\right), 2.38$ (s, $\left.4 \mathrm{H}, \mathrm{CH}_{2}\right)$.

\section{Synthesis 1,2-ethanediaminium, $N^{1}, N^{2}$ bis[2-(decyloxy)-2-oxoethyl]- $N^{1}, N^{1}, N^{2}, N^{2}$-tetramethyl-chloride (Ethonium)}

In a $100 \mathrm{~cm}^{3}$ round-bottom flask, equipped with a magnetic stirrer and a condenser 0.01 mole ( 1 eq.) $\mathrm{N}^{1}, \mathrm{~N}^{1}, \mathrm{~N}^{2}, \mathrm{~N}^{2}$-tetramethylethane-1,2-diamine in $10 \mathrm{ml}$ acetonitrile was placed. Then 0.21 mole (2 eq.) decyl 2- chloroacetate was added dropwise to reaction mixture. The mixture was refluxed for 30 hours, cooled and resulting product was filtered off. Yield 30\%, m.p. $164-165^{\circ} \mathrm{C} . \mathrm{NMR}{ }^{1} \mathrm{H}\left(\mathrm{d}_{6}-\mathrm{DMSO}, \delta ., \mathrm{ppm}, J / \mathrm{Hz}\right)$ : $0.88\left(\mathrm{~m}, 6 \mathrm{H}, 2 \mathrm{CH}_{2} \mathrm{CH}_{3}\right), 1.28(\mathrm{~s}, 32 \mathrm{H}, 32 \mathrm{CH}), 1.66\left(\mathrm{~m}, 4 \mathrm{H}, 2 \mathrm{CH}_{2}\right), 3.32\left(\mathrm{~s}, 6 \mathrm{H}, 2 \mathrm{NCH}_{3}\right), 3.43(\mathrm{~s}, 6 \mathrm{H}$, $\left.2 \mathrm{NCH}_{3}\right), 4.2\left(\mathrm{~m}, 4 \mathrm{H}, \mathrm{NCH}_{2} \mathrm{CH}_{2} \mathrm{~N}\right), 4.39\left(\mathrm{~s}, 2 \mathrm{H}, \mathrm{CH}_{2} \mathrm{COOC}_{10} \mathrm{H}_{21}\right), 4.71\left(\mathrm{~s}, 2 \mathrm{H}, \mathrm{CH}_{2} \mathrm{COOC}_{10} \mathrm{H}_{21}\right)$. LCMS $m / z\left(\mathrm{M}+\mathrm{H}^{+}\right)=514.07, m / z\left(\mathrm{M}+\mathrm{H}^{+}\right)=316.28, m / z\left(\mathrm{M}+\mathrm{H}^{+}\right)=244.24$.

\section{RESULTS AND DISCUSSION}

The general method of Ethonium synthesis was investigated in the Ukraine Institution of Organic Chemistry. The scheme consists of two stages. The first stage is nucleophilic substitution dichloroethane and dimethylamine. The reaction is passed with high pressure (100 atm.) in the reactor. The second stage is the alkylation of the tertiary amine by decyl-2-chloroacetate in benzene. Summary yield is $11 \%$ without investigation of decyl 2-chloroacetate synthesis.

We have realized two technologically available and cheap Ethonium syntheses. Pathways involved stage of decyl-2-chloroacetate synthesis (stage 1); TMEDA synthesis (stage 2) and alkylation of TMEDA by decyl-2-chloroacetate (stage 3). The synthesis scheme is presented below (Scheme-1).

Our purpose was a high yield of decyl 2- chloroacetate and decrease its cost. Decyl 2- chloroacetate was obtained by two methods. The first way is etherification. The second way is the acylation of n-decanol by 2- chloroacetyl chloride (Scheme-2). In our experiments, we tested several solvents, also varied ratios of 2- 
chloroacetic acid, n-decanol and TsOH. We determined the optimal conditions of the reaction. Maximum yield $(83 \%)$ was performed in a mixture of xylenes at $149^{\circ} \mathrm{C}$, the molar ratio is 2-chloroacetic acid : $\mathrm{n}$ decanol : TsOH $-1.2: 1: 0.001$ after $5 \mathrm{~h}$ of reflux (entry 3 ). Further experiments showed that decreasing reaction temperature (entries $1,2,4$ ) reduced the yield of the product. In addition, increasing the molar ratio of n-decanol did not improve the yield (entry 5). (Table-1).

Stage 1

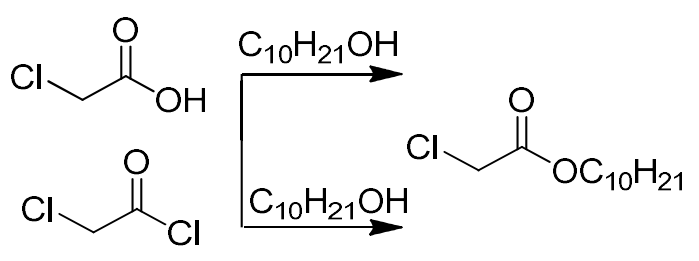

Stage 2

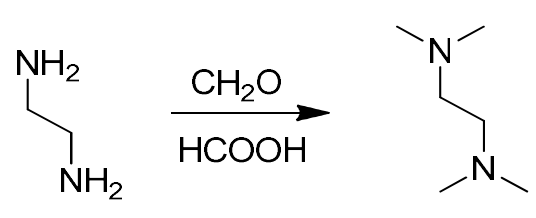

Stage 3

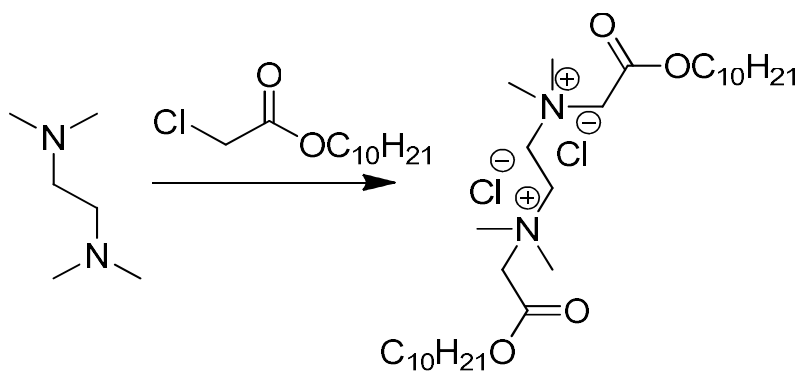

Scheme-1: Investigation of Preparation Methods of decyl 2-chloroacetate<smiles>CCOC(=O)CCl</smiles>

Scheme-2: Investigation of decyl 2- chloroacetate Synthesis

\section{Investigation of TMEDA Preparation}

Nowadays several types of amine methylation have been described: amine alkylation by dimethyl sulfate or methylation amine by a mixture of formalin with formic acid ${ }^{16}$ (Eschweiler-Clarke method). Huang and coworkers described a method of $\mathrm{N}$ - alkylation of TMEDA using methanol and $\mathrm{CuO}-\mathrm{NiO} / \gamma-\mathrm{Al}_{2} \mathrm{O}_{3}$ as the catalyst. ${ }^{17}$ Also, TMEDA synthesis was described by Rosenau and coworkers. They noted solvent-free and formalin-free methylation of amines by the Eschweiler-Clarke method, such as ethylenediamine. ${ }^{18}$ Other works described reductive Nickel Raney N-methylation of amines with paraformaldehyde. We used classic methylation of amine by Eschweiler-Clarke (Scheme-3). It's a cheap and useful method.

In our experiments, we used an initial sample of ethylenediamine with a purity of $99 \%$ and transfer standard TMEDA with a purity of $99 \%$. 
RASĀYAN J. Chem.

Vol. 14 | No. 3 |1816-1820| July - September | 2021

Table-1: Optimization of decyl 2-chloroacetate Synthesis

\begin{tabular}{c|c|c|c|c|c}
\hline Entry & Solvent & $\begin{array}{c}\text { Temperature, } \\
{ }^{\circ} \mathrm{C}\end{array}$ & $\begin{array}{c}\text { Reaction time, } \\
\mathrm{t}, \mathrm{h} .\end{array}$ & $\begin{array}{c}\text { Molar ratio of } \\
\text { 2-chloroacetic : acid : } \\
\text { n-decanol : PTSA }\end{array}$ & $\begin{array}{c}\text { Yield } \\
(\%)\end{array}$ \\
\hline 1 & toluene & 110.6 & 5 & $1,2: 1: 0.001$ & 74 \\
\hline 2 & o-xylene & 144.0 & 5 & $1,2: 1: 0.001$ & 59 \\
\hline 3 & $\begin{array}{c}\text { mixture of } \\
\text { xylenes } \\
(\mathrm{o}-, \mathrm{m}-, \mathrm{p})\end{array}$ & 149.0 & 5 & $1,2: 1: 0.001$ & 83 \\
\hline 4 & cyclohexane & 80.7 & 5 & $1,2: 1: 0.001$ & 66 \\
\hline 5 & benzene & 80.1 & 5 & $1,2: 1: 0.001$ & 74 \\
\hline 6 & benzene & 80.1 & 5 & $1: 1,4: 0.001$ & 64 \\
\hline
\end{tabular}

A series of experiments according to the procedure described. ${ }^{16}$ According to this procedure formic acid $(85 \%)$ was added gradually to ethylenediamine, then formalin was added to the reaction mixture. The ratio of ethylenediamine : formic acid : formalin was 1:8.4:5 respectively. Then the reaction mixture was refluxed for 10 hours then TMEDA was isolated in $57 \%$ yield. When the time of reaction was increased, the yield of TMEDA became $64 \%$. The decrease of yield is commonly explained by the formation of formaldehyde polycondensation products, which can be avoided by changing the sequence and rates of adding reagents. Experiments were performed by gradually adding the amine to the heated mixture of formalin and formic acid. The influence on the yield of TMEDA was researched by various temperatures of the reaction mixture when adding the initial amine, the concentration of formic acid and the reaction time. Experiments were also carried out to reduce the excess of formic acid.

It was found that reducing the excess of formic acid even by $15-20 \%$ significantly reduced the yield of TMEDA (entries 1-3). When the reaction was carried out with $85 \%$ formic acid, the yield of the product was increased to $93 \%$ (entries 7-8). The optimal time of reflux was $5 \mathrm{~h}$. Furthermore, it was found, that the optimal temperature of ethylenediamine adding to the methylating mixture was $80{ }^{\circ} \mathrm{C}$. At the lower temperature, the yield slightly decreased, but the increase of methylating mixture temperature is limited by the physicochemical properties of the mixture of formaldehyde and formic acid. The research results are presented in Table-2.

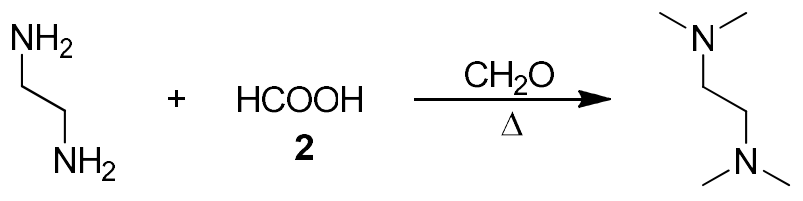

1

3

Scheme-3: Investigation of TMEDA Synthesis

Table-2: Optimization of TMEDA Synthesis

\begin{tabular}{c|c|c|c|c|c}
\hline Entry & $\begin{array}{c}\text { Temperature of } \\
\text { reaction mixture } \\
\text { when } 1 \text { was } \\
\text { added }\end{array}$ & $\begin{array}{c}\text { Quantity of 2, } \\
\text { mole }\end{array}$ & $\begin{array}{c}\text { Concentration of 2, } \\
\%\end{array}$ & $\begin{array}{c}\text { Time of } \\
\text { reaction, } \tau\end{array}$ & Yield of 3, \% \\
\hline 1 & $78-80$ & 0.42 & 100 & 9 & 74 \\
\hline 2 & $78-80$ & 0.33 & 100 & 9 & 29 \\
\hline 3 & $78-80$ & 0.36 & 100 & 9 & 54 \\
\hline 4 & $65-70$ & 0.42 & 100 & 9 & 72 \\
\hline 5 & $78-80$ & 0.42 & 100 & 1 & 32 \\
\hline 6 & $78-80$ & 0.42 & 100 & 4 & 36 \\
\hline $7^{*}$ & $78-80$ & 0.42 & 100 & 9 & 79 \\
\hline $9^{*}$ & $78-80$ & 0.42 & 85 & 9 & 93 \\
\hline $10^{*}$ & $78-80$ & 0.42 & 85 & 7 & 98 \\
\hline
\end{tabular}

*-TMEDA was distilled without draining by sodium hydroxide 


\section{Investigation of Ethonium Preparation}

The alkylation of TMEDA by decyl 2-chloroacetate was carried out according to the procedure described earlier $^{7}$ with slight modification. We used acetonitrile as solvent. Ethonium was isolated in $30 \%$ yield. The total yield of Ethonium achieved $20 \%$ and it's higher than described earlier.

\section{CONCLUSION}

Ethonium is an antiseptic, disinfectant drug with antibacterial, fungicidal activity. It was synthesized by 3 stage scheme. The scheme was researched. At the first stage decyl 2-chloro-acetate synthesis was optimized. The highest yield (83\%) was achieved using a mixture of xylenes and a ratio of 2-chloroacetic acid : n-decanol : TsOH - 1.2:1:0.001. At the stage of TMEDA synthesis was found optimal conditions of methylation of ethylenediamine by Eschweiler-Clarke method in $98 \%$ yield. The ratio of ethylenediamine: formic acid (85\%): formalin was 1:8.4:5 respectively, optimal temperature of reaction mixture when adding ethylenediamine is $78-80^{\circ} \mathrm{C}$, optimal reaction time is 5 hours. At the last stage of TMEDA alkylation, we suggested acetonitrile such a solvent. The total yield is $20 \%$.

\section{REFERENCES}

1. M. Tischer, G. Pradel, K. Ohlsen and U. Holzgrade, ChemMedChem, 7, 22(2011), https://doi.org/10.1002/cmdc.201100404

2. T. Sumitomo, T. Maeda, H. Nagamune and H. Kourai, Biocontrol Science, 9, 1 (2004)

3. E. Obłaka, A. Piecucha, A. Krasowskab and J. Łuczy'nskic, Microbiological Research, 168, 630(2013), https://doi.org/10.1016/j.micres.2013.06.001

4. E. Obłąka, A. Piecucha, E. Dworniczek and T. Olejniczak, Journal of Oleo Science, 64, 527 (2015), https://doi.org/10.5650/jos.ess 14195

5. R. Sharma, A. Kamal and M. Abdineag, Colloid and Interface Science, 248, 35 (2017), https://doi.org/10.1016/j.cis.2017.07.032

6. J. Hoque, P. Akkapeddi and V. Yarlagadda, Langmuir, 28, 12225 (2011), https://doi.org/10.1021/la302303d

7. E. Obłaka, A. Piecuch, K. Guz-Regner and E. Dworniczek, FEMS Microbiology Letters, 250, 190 (2014), https://doi.org/10.1111/1574-6968.12331

8. P. Raji, A.V. Samrot, D.B. Rohan, P.D. Kumar, R. Geetika, V.K. Sharma and D. Keerthana, Rasayan Journal of Chemistry, 12(1), 123(2019), https://doi.org/10.31788/RJC.2019.1214054

9. R. Hardiyanti, L. Marpaung, I.K. Adnyana and P. Simanjuntak, Rasayan Journal of Chemistry, 12(4), 1822 (2019), https://doi.org/10.31788/RJC.2019.1235353

10. M. Idrees, S. Kola and N.J. Siddiqui, Rasayan Journal of Chemistry, 12(4), 1725(2019), https://doi.org/10.31788/RJC.2019.1245467

11. O. Goncharuk, V. Gunko and A. Ugnivenko, Nano Research and Applications, 3, 29(2017), https://doi.org/10.21767/2471-9838.100029

12. N. Tokareva, S. Zykova, and V. Talismanov, E3S Web of Conferences, 217, 08006(2020), https://doi.org/10.1051/e3sconf/202021708006

13. A.I. Pertsovskii, N.S. Kononova and L.N. Chukreeva, Vrachebnoye Delo, 4, 103(1990)

14. O.I. Babak and I.E. Kushni, Lik Sprava, 3-4, 123(1996)

15. S.S. Zykova, G.V. Tsaplin, V.S. Talismanov, I.P. Bulatov, S.V. Popkov and O. Karmanova International Journal of Pharmaceutical Research, 13, 309(2021), https://doi.org/10.31838/ijpr/2021.13.01.056

16. H. Clarke, H. Gillespie and S.J. Weisshaus, Journal of American Chemical Society, 55, 4571(1933) https://doi.org/10.1021/ja01338a041

17. J.-M. Huang, L.-F. Xu, C. Qian and X.-Z. Chen, Chemical Papers, 66, 304(2012), https://doi.org/10.2478/s1 1696-012-0140-8

18. T. Rosenau, A. Potthast, J. Rohrling, A. Hofinger, H. Sixta and P.A. Kosma, Synthetic Communications, 32, 457(2002), https://doi.org/10.1081/SCC-120002131

[RJC-6574/2021] 